\title{
Large- and medium-sized ungulates in the Haut Niger National Park, Republic of Guinea: population changes 1997-2002
}

\author{
David Brugière, Mamadou Dia, Souleymane Diakité, Marthe Gbansara, Maurice Mamy, \\ Barry Saliou and Bakary Magassouba
}

\begin{abstract}
A census of ungulates was carried out in May 2002 in the Haut Niger National Park, Republic of Guinea. The study site was subdivided into three census blocks in which a total 111 transects (total length $=838.24 \mathrm{~km}$ ) were censused once by one observer. Densities were estimated using DISTANCE analysis. We observed a total of 10 species of ungulates (nine Bovidae and one Suidae). Maxwell's duiker Cephalophus maxwelli had the highest density (3.69 individuals $\mathrm{km}^{-2}$ ) followed by the red-flanked duiker Cephalophus rufilatus (2.61 individuals $\mathrm{km}^{-2}$ ), whereas the buffalo Syncerus caffer had the lowest density (0.34 individuals $\mathrm{km}^{-2}$ ). Compared to a census in 1997, the abundance of red-flanked and Maxwell's duikers significantly decreased (by c. $50 \%$ )
\end{abstract}

whereas that of other species remained stable or increased. This variation may possibly be explained by a change in the hunting pattern in the area, which shifted from large-scale hunting by large groups of hunters from outside the area before the Park's creation, to small-scale poaching by local hunters. The Park includes a diversity of ungulate species and harbours populations of ungulates that are important at both national and regional levels. We recommend therefore that the Park should be considered a key area for the conservation of ungulates in West Africa.

Keywords Census, density, Guinea, Haut Niger National Park, poaching, ungulates.

\section{Introduction}

Until recently the conservation of biodiversity was given a low priority in the Republic of Guinea and, as a result, even basic data on the distribution of larger animal species are incomplete (Barnett \& Prangley, 1997; East, 1999). A shift in government policy occurred in the 1990s with the onset of several conservation projects. In this context, the Haut Niger National Park was created in 1997 to protect one of the last remnants of dry forest vegetation in the country. This Park is of national importance for the conservation of biodiversity in Guinea because it is the largest protected area devoted to biodiversity conservation and it protects threatened dry forest habitat and vertebrate species whose populations are locally or regionally declining (Ziegler et al., 2002). The Mafou forest, one of the two core areas of the Park, has always been considered an important hunting area

David Brugière (Corresponding author) Programme AGIR, Parc National du Haut Niger, BP 730, Conakry, Republic of Guinea.

E-mail dmc_brugiere@yahoo.fr

Mamadou Dia, Marthe Gbansara, Maurice Mamy and Barry Saliou Direction Nationale des Eaux et Forets, BP 624, Conakry, Republic of Guinea.

Souleymane Diakité and Bakary Magassouba Parc National du Haut Niger, BP 624, Conakry, Republic of Guinea.

Received 1 March 2004. Revision requested 9 June 2004 Accepted 13 August 2004. by local people. In 1995 Ziegler (1996) surveyed the bushmeat trade in villages located close to the Mafou forest and found that ungulate species accounted for the bulk of the animals offered for sale. In 1997 Touré et al. (1997) carried out a census of mammals in a small section of the Mafou forest and provided the first data on species abundance. At that time, the Park infrastructure was under construction and law enforcement was not yet effective, and thus figures of animal abundance reflect populations under strong hunting pressure. In 2002, after 6 years of Park management, a new census focusing on ungulates was carried out in the Mafou forest. Here we present the results of this survey, discuss the trends in ungulate populations, and assess the significance of the Park for the conservation of ungulates.

\section{Study area}

The Haut Niger National Park covers c. 10,000 km² and includes two sectors, $60 \mathrm{~km}$ apart, each having a core area (the Mafou forest, $554 \mathrm{~km}^{2}$, and the Kouya forest, $675 \mathrm{~km}^{2}$ ) and a buffer zone (Fig. 1). The core areas are free of human settlements, but there are c. 80,000 inhabitants in total in the two buffer zones. Annual rainfall is $c$. $1,400 \mathrm{~mm}$ and the dry season is from November to March. The Mafou core area includes herbaceous savannah, wooded savannah, dry forest and gallery forest. The mammal fauna of the Park includes 94 species, 
which is c. $50 \%$ of the country's known mammalian diversity (Ziegler et al., 2002; Brugière \& Magassouba, 2003). For a full description of the Park, see Ziegler et al. (2002).

\section{Methods}

The census was carried out in May 2002, i.e. at the onset of the rains when new grass growth is still short and small water holes have formed throughout the Park. For the purpose of the census, the Mafou forest was subdivided into three census blocks (B1, B2 and B3, from west to east; Fig. 1) in which a total of 111 transects of variable length $(0.7-14.2 \mathrm{~km})$ were set. The cumulative length of the transects was $838.24 \mathrm{~km}$ and the stratification by block was 72 parallel transects $(580.10 \mathrm{~km})$ in B1, 15 parallel transects $(130.27 \mathrm{~km})$ in $\mathrm{B} 2$, and 24 parallel transects $(127.87 \mathrm{~km})$ in B3. The census area covered $c$. $50 \%$ of Mafou forest. Each transect was walked once by one observer early in the morning. A total of 15 people were simultaneously involved in the survey and all were experienced field observers (Park and central wildlife agency staff whose accuracy in recognizing species and estimating distances had been tested in several training sessions and on other surveys). Every time a group of animals was observed, the total number was recorded and a visual estimate made of the perpendicular distance between the first animal observed and the transect. Field observers also recorded the distance between the first animal seen and the geometric centre of the group (i.e. group spread) when appropriate, but in practice group size of all encountered species was too small (see Table 1) to obtain reliable group spread. The density of species encountered $>12$ times was calculated using DISTANCE (Laake et al., 1994). Three detection functions (uniform, half-normal and hazard-rate) were tested and the best model was selected according to the Akaike information criterion (Buckland et al., 1993). For species for which the sample size was too small to reliably estimate densities from distance sampling, we present the encounter rate (defined as the number of individuals observed per $10 \mathrm{~km}$ ). Ungulate taxonomy follows Kingdon (1997).

\section{Results}

We identified a total of 10 species of ungulates (nine Bovidae and one Suidae; Table 1). Overall, the red-flanked duiker Cephalophus rufilatus and Maxwell's duiker C. maxwelli were the most commonly observed (accounting for $24.4 \%$ and $19.4 \%$ of the total number of animals counted, respectively) while the oribi Ourebia ourebi and the kob Kobus kob were the least observed $(0.2 \%$ and $3.3 \%$, respectively).

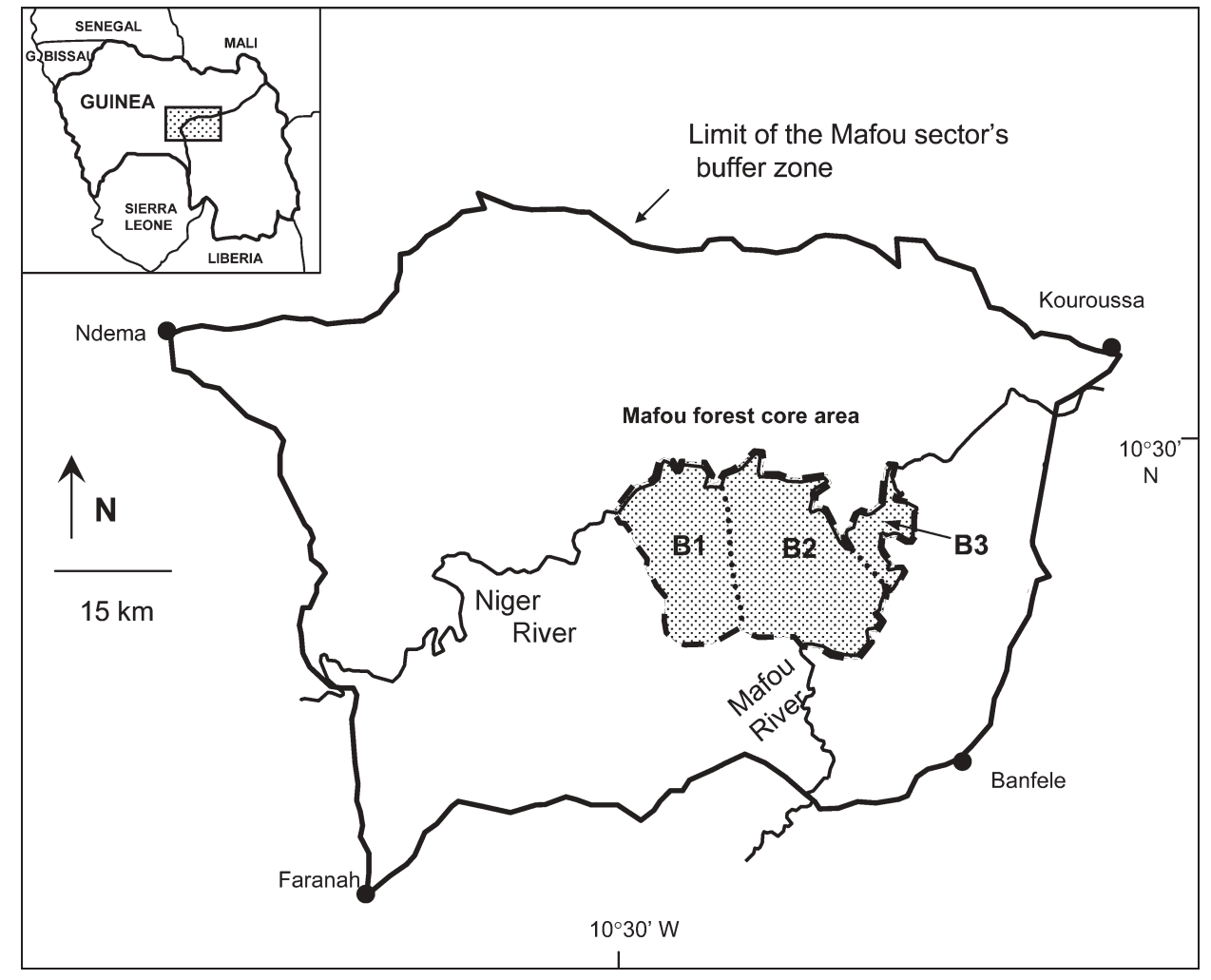

Fig. 1 The Mafou sector of the Haut Niger National Park with the location of the three census blocks (B1-B3) within the core area. The shaded rectangle in the inset indicates the location of the main figure in Guinea. 
Table 1 Species observed during the census, with their Red List status, number of contacts and individuals of each species, encounter rate (numbe of animals counted per $10 \mathrm{~km}$ ) in each census block (B1-B3) and mean and range of group size.

\begin{tabular}{|c|c|c|c|c|c|c|c|c|}
\hline \multirow[b]{2}{*}{ Species } & \multirow[b]{2}{*}{ Red List status ${ }^{1}$} & \multirow{2}{*}{$\begin{array}{l}\text { Number } \\
\text { of contacts }\end{array}$} & \multirow{2}{*}{$\begin{array}{l}\text { Number of } \\
\text { animals } \\
\text { counted }\end{array}$} & \multicolumn{3}{|c|}{ Encounter rate $( \pm \mathrm{SE})^{2}$} & \multicolumn{2}{|l|}{ Group size } \\
\hline & & & & B1 & B2 & B3 & Mean \pm SE & Range \\
\hline Hartebeest Alcelaphus buselaphus & $\mathrm{LR} / \mathrm{cd}$ & 8 & 25 & $0.38 \pm 0.08^{\mathrm{a}}$ & $0.23 \pm 0.13^{\mathrm{a}}$ & 0.00 & $3.1 \pm 1.0$ & $2-15$ \\
\hline $\begin{array}{l}\text { Maxwell's duiker } \\
\text { Cephalophus maxwelli }\end{array}$ & & 62 & 81 & $1.02 \pm 0.13^{\mathrm{a}}$ & $1.46 \pm 0.33^{\mathrm{a}}$ & $0.23 \pm 0.13^{\mathrm{b}}$ & $1.3 \pm 0.1$ & $1-3$ \\
\hline $\begin{array}{l}\text { Red-flanked duiker } \\
\text { Cephalophus rufilatus }\end{array}$ & $\mathrm{LR} / \mathrm{cd}$ & 93 & 102 & $1.52 \pm 0.16^{\mathrm{a}}$ & $0.54 \pm 0.20^{\mathrm{b}}$ & $0.55 \pm 0.20^{\mathrm{b}}$ & $1.1 \pm 0.0$ & $1-2$ \\
\hline $\begin{array}{l}\text { Yellow-backed duiker } \\
\text { Cephalophus silvicultor }\end{array}$ & $\mathrm{LR} / \mathrm{nt}$ & 21 & 24 & $0.34 \pm 0.08^{\mathrm{a}}$ & $0.31 \pm 0.15^{\mathrm{a}}$ & 0.00 & $1.1 \pm 0.1$ & $1-2$ \\
\hline Waterbuck Kobus ellipsiprymnus & $\mathrm{LR} / \mathrm{cd}$ & 14 & 39 & $0.43 \pm 0.08^{\mathrm{a}}$ & $0.92 \pm 0.26^{\mathrm{b}}$ & $0.16 \pm 0.11^{c}$ & $2.8 \pm 0.2$ & $1-5$ \\
\hline Kob Kobus kob & $\mathrm{LR} / \mathrm{cd}$ & 4 & 14 & 0.00 & $0.92 \pm 0.26^{\mathrm{a}}$ & $0.16 \pm 0.11^{\mathrm{b}}$ & $3.5 \pm 0.5$ & $2-6$ \\
\hline Oribi Ourebia ourebi & $\mathrm{LR} / \mathrm{cd}$ & 1 & 1 & $0.02 \pm 0.02$ & 0.00 & 0.00 & 1.0 & 1 \\
\hline $\begin{array}{l}\text { Common warthog } \\
\text { Phacochoerus africanus }\end{array}$ & & 8 & 38 & $0.60 \pm 0.10^{a}$ & $0.23 \pm 0.13^{b}$ & 0.00 & $4.8 \pm 0.5$ & $2-12$ \\
\hline African buffalo Syncerus caffer & $\mathrm{LR} / \mathrm{cd}$ & 13 & 39 & $0.57 \pm 0.01^{a}$ & 0.00 & $0.47 \pm 0.19^{\mathrm{a}}$ & $3.0 \pm 0.6$ & $1-12$ \\
\hline Bushbuck Tragelaphus scriptus & & 39 & 55 & $0.90 \pm 0.12^{\mathrm{a}}$ & $0.15 \pm 0.01^{\mathrm{b}}$ & $0.08 \pm 0.08^{c}$ & $1.4 \pm 0.1$ & $1-12$ \\
\hline Total & & 263 & 418 & $5.78 \pm 1.74^{\mathrm{a}}$ & $4.76 \pm 1.36^{\mathrm{a}}$ & $1.65 \pm 0.60^{\mathrm{b}}$ & & \\
\hline
\end{tabular}

${ }^{1}$ IUCN, 2003. LR/cd, Lower Risk/conservation dependent; LR/nt, Lower Risk/near threatened

${ }^{2}$ Significant differences in pairwise comparisons (Mann-Whitney $\mathrm{U}$ test, one-tailed, $\mathrm{P}<0.05$ ) of encounter rates between blocks are indicated by values that do not share a common superscripted letter.

Encounter rate of species varied significantly between census blocks (Kruskal-Wallis test, $\mathrm{P}=0.01$ ). Four species were not recorded in $\mathrm{B} 3$ and five of the six species observed in the three blocks were significantly more abundant in B1 or B2 (Table 1). Only the buffalo Syncerus caffer did not show a significant difference in encounter rate between B1 and B3. Overall, there was a decrease in ungulate abundance from west to east in the Mafou core area.

DISTANCE analysis for the six species observed more than 12 times is presented in Table 2. As expected, the effective strip width (i.e. the distance from the transect line within which individuals could be reliably observed) for each species tended to increase with height at shoulder, being smallest for Maxwell's duiker $(13.0 \mathrm{~m})$ and largest for buffalo $(47.6 \mathrm{~m})$. Overall, there was a strong negative correlation between the density of the species in the study site and their body weight (Spearman rank correlation test, $\mathrm{r}_{\mathrm{s}}=-1$; body weight of adult males taken from Kingdon, 1997). Maxwell's duiker had the highest density (3.69 individuals $\mathrm{km}^{-2}$ ), followed by the red-flanked duiker (2.61 individuals $\mathrm{km}^{-2}$ ), and buffalo had the lowest density (0.34 individuals $\mathrm{km}^{-2}$ ). The waterbuck Kobus ellipsiprymnus is known to be restricted to habitat close to watercourses (Kingdon, 1982) and we therefore calculated the density of this species in the area within $2.5 \mathrm{~km}$ of the Niger and Mafou rivers (the maximum distance at which tracks of

Table 2 For those species observed more than 12 times in the Mafou core area, the best model, effective strip width, group density, individual density (with 95\% confidence interval), and estimate of population size (with $95 \%$ confidence interval from the DISTANCE analysis, see text for details).

\begin{tabular}{|c|c|c|c|c|c|}
\hline Species & Best model & Effective strip width (m) & Group density $\left(\mathrm{km}^{-2}\right)$ & $\begin{array}{l}\text { Individual density } \\
(95 \% \mathrm{CI})\left(\mathrm{km}^{-2}\right)\end{array}$ & Population size $(95 \%$ CI) \\
\hline Maxwell's duiker & Half-normal & $13.0(12.2)$ & 2.82 & $3.69(2.89-4.69)$ & $2,046(1,601-2,598)$ \\
\hline Red-flanked duiker & Half-normal & $23.3(9.3)$ & 2.38 & $2.61(2.17-3.14)$ & $1,446(1,202-1,739)$ \\
\hline Yellow-backed duiker & Uniform & $18.1(28.7)$ & 0.69 & $0.79(0.45-1.43)$ & 438 (249-792) \\
\hline Waterbuck $^{1}$ (a) & Half-normal & $30.0(22.7)$ & 0.96 & $2.68(1.65-4.36)$ & $536(330-871)$ \\
\hline (b) & Half-normal & $30.0(22.7)$ & 0.27 & $0.78(0.48-1.27)$ & $432(266-704)$ \\
\hline African buffalo & Hazard-rate & $47.6(29.5)$ & 0.16 & $0.34(0.11-0.99)$ & $189(61-548)$ \\
\hline Bushbuck & Uniform & $27.4(7.2)$ & 0.84 & $1.19(1.03-1.38)$ & $662(571-765)$ \\
\hline
\end{tabular}

${ }^{1}$ (a) In areas within $2.5 \mathrm{~km}$ of the Niger and Mafou rivers $\left(200 \mathrm{~km}^{2}\right.$ of the core area; see text for details), (b) Over the whole of the core area. 
waterbuck were observed). This gave a density of 2.68 individuals $\mathrm{km}^{-2}$; for the whole of the census the density of the waterbuck was 0.78 individuals $\mathrm{km}^{-2}$.

Assuming that the species densities estimated in the sampled area are valid over the whole of the Mafou core area, the populations of the two most abundant species, Maxwell's duiker and the red-flanked duiker, were estimated at 2,050 and 1,450 individuals, respectively, whereas the buffalo population was estimated to be 189 individuals.

\section{Discussion}

Results of the 2002 census are not directly comparable with those of the 1997 census (Touré et al., 1997) because the study site was not sampled with the same intensity (c. 50\% of the Mafou forest was sampled in 2002 whereas $<10 \%$ was covered in 1997) and animal densities were not calculated with the same methods. We therefore compared encounter rates of species observed in either or both 1997 and 2002 in the area covered by the two censuses. Five out of the ten ungulates species showed a significant increase in encounter rate between 1997 and 2002 (Table 3). For the two largest species, buffalo and hartebeest Alcephalus buselaphus, this increase $(\geqslant 100 \%)$ should be interpreted with caution because the absolute number of observations was small $(n<7)$ in both 1997 and 2002. Similarly, the lack of observation for the giant hog Hylochoerus meinertzhageni in 2002 does not give any clear indication of the population trend of this species because it was observed only twice in 1997. There were significant increases in encounter rates of the

Table 3 Comparison of encounter rates (number of animals counted per $10 \mathrm{~km}$ walked) ( $\pm \mathrm{SE}$ ) of species observed during the 1997 (Touré et al., 1997) and 2002 (this study) censuses, and \% variation between censuses.

\begin{tabular}{lcll}
\hline \multicolumn{3}{c}{$\begin{array}{c}\text { Year (distance } \\
\text { censused, km) }\end{array}$} & \\
\cline { 2 - 3 } Species & Variation \\
& $1997(357.5)$ & $2002(125.0)$ & $1997-2002(\%)$ \\
\hline Hartebeest & $0.17 \pm 0.14$ & $0.40 \pm 0.41^{*}$ & +135 \\
Maxwell's duiker & $2.88 \pm 0.89^{*}$ & $1.52 \pm 0.54$ & -47 \\
Red-flanked duiker & $5.90 \pm 1.11^{*}$ & $2.48 \pm 1.54$ & -58 \\
Yellow-backed duiker & $0.11 \pm 0.15$ & $0.48 \pm 0.52^{*}$ & +336 \\
Giant hog Hylochoerus & $0.06 \pm 0.05$ & 0.00 & -100 \\
$\quad$ meinertzhageni & & & \\
Waterbuck & $0.90 \pm 0.67$ & $2.00 \pm 1.71^{*}$ & +122 \\
Kob & $0.20 \pm 0.11$ & 0.00 & -100 \\
Common warthog & $0.62 \pm 0.50$ & $1.84 \pm 0.40^{*}$ & +196 \\
African buffalo & 0.00 & $0.08 \pm 0.03$ & +100 \\
Bushbuck & $2.01 \pm 0.29$ & $2.08 \pm 0.90$ & +3 \\
Total & $12.85 \pm 2.69$ & $10.88 \pm 3.42$ & \\
\hline
\end{tabular}

*significantly higher (Mann-Whitney U test, one-tailed, $\mathrm{P}<0.05)$. warthog Phacochoerus africanus, waterbuck and yellowbacked duiker Cephalophus silvicultor but significant decreases in the medium-sized Maxwell's and redflanked duikers. Ziegler (1996) found that these two duikers were the first and fourth most abundant species, respectively, in local bushmeat markets, accounting for $36 \%$ of the total number of animals offered for sale in 1995 ( $n=3,845 ; 19$ species). The fact that these two species appear to have declined from 1997 to 2002, whereas other ungulates species increased or remained stable, may be explained by changes in hunting patterns in the area. Whereas hunters used to come from the whole of the Haut Niger region and hunted in large groups for several weeks in the Mafou forest prior to its gazettement as a core area of the Park in 1997, solitary or small groups of hunters now come mainly from nearby villages and enter the forest for short periods ( $<12$ hours). They hunt opportunistically, almost exclusively by night (pers. obs.), and hence focus on the most abundant species. Similarly, Fischer \& Linsenmair (2001) observed that the species that declined the most in the poached sectors of the Comoé National Park, Ivory Coast, were the duikers and small ungulates up to the size of the kob. The observation of a decrease in ungulate abundance from west to east in the Mafou core area is probably explained by the proximity of populated villages to the eastern part of the core area.

Six out of the 10 ungulate species observed during the census survey are categorized on the Red List (IUCN, 2003; Table 1) as Lower Risk/conservation dependent. In Guinea, the Haut Niger National Park is the only one of the three protected areas that protects significant populations of ungulates (no large ungulates were seen during the last census in the Badiar National Park (Sillero-Zubiri et al., 1997) and only limited populations of forest antelopes occur in the Nimba Strict Nature Reserve (Lamotte, 1998). At a regional scale, comparative data from nearby protected areas indicate that the abundance of several ungulates species are relatively high in the Park, particularly bushbuck, Maxwell's duiker, red-flanked duiker and buffalo (Table 4). This suggests that the Park could play an important role in the conservation of these species at the regional level. In addition, the Park occupies a geographical position corresponding to the southern limit of several savannah species (e.g oribi, hartebeest, and roan antelope Hippotragus equinus, the latter only occurring seasonally) and the northern limit of several forest-dwelling ungulates (e.g. red river hog Potamocherus porcus, and chevrotain Hyemoscus aquaticus, the latter not observed during our census but present in the Mafou forest). The protection of populations at the edge of their range is important for the conservation of the genetic diversity of the species (Pector, 2003).

Based on the facts that Haut Niger National Park harbours significant populations of ungulates at both 
Table 4 Comparative data for encounter rate (animals counted per $10 \mathrm{~km}$ walked) and density (individual $\mathrm{km}^{-2}$ ) of ungulate species in four West African protected areas.

\begin{tabular}{|c|c|c|c|c|c|c|c|c|}
\hline & \multicolumn{2}{|c|}{$\begin{array}{l}\text { Haut-Niger National } \\
\text { Park (Guinea) }\end{array}$} & \multicolumn{2}{|c|}{$\begin{array}{l}\text { Niokolo-koba National } \\
\text { Park (Senegal) }\end{array}$} & \multicolumn{2}{|l|}{$\begin{array}{l}\text { Nazinga Ranch } \\
\text { (Burkina-Faso) }\end{array}$} & \multicolumn{2}{|c|}{$\begin{array}{l}\text { Comoé National } \\
\text { Park (Ivory Coast) }\end{array}$} \\
\hline & Encounter rate & Density & Encounter rate & Density & Encounter rate & Density & Encounter rate & Density \\
\hline Hartebeest & 0.30 & $\mathrm{NA}^{1}$ & 0.31 & 0.3 & 2.61 & 1.18 & NA & 0.45 \\
\hline Maxwell's duiker & 0.97 & 3.69 & $\mathrm{~A}^{2}$ & - & A & - & NA & 0.04 \\
\hline Red-flanked duiker & 1.22 & 2.61 & 0.43 & 0.9 & NA & NA & NA & 0.14 \\
\hline Waterbuck $^{3}$ (a) & 0.47 & 0.78 & 0.23 & 0.1 & 1.94 & 1.57 & NA & NA \\
\hline (b) & 1.60 & 2.68 & NA & NA & NA & 3.71 & NA & 0.08 \\
\hline Kob & 0.17 & NA & 1.97 & 0.8 & 0.42 & NA & NA & 1.10 \\
\hline Oribi & 0.01 & NA & 0.27 & 0.6 & 0.60 & 0.32 & NA & 0.19 \\
\hline Common warthog & 0.45 & NA & 2.57 & 2.6 & 5.03 & 5.65 & NA & 0.06 \\
\hline African buffalo & 0.47 & 0.34 & 0.02 & $0.1^{4}$ & 0.25 & 0.08 & NA & 0.40 \\
\hline Bushbuck & 0.66 & 1.19 & 0.80 & 1.4 & 0.63 & 0.84 & NA & 0.08 \\
\hline Reference & \multicolumn{2}{|l|}{ This study } & \multicolumn{2}{|l|}{ Galat et al. (1998) } & \multicolumn{2}{|l|}{ Cornelis (2000) } & \multicolumn{2}{|c|}{ Fisher \& Linsenmair (2001) } \\
\hline $\begin{array}{l}\text { Geographic } \\
\text { coordinates }^{5}\end{array}$ & \multicolumn{2}{|l|}{$10^{\circ} 50^{\prime} \mathrm{N}-10^{\circ} 50^{\prime} \mathrm{W}$} & \multicolumn{2}{|l|}{$13^{\circ} 00^{\prime} \mathrm{N}-13^{\circ} 00^{\prime} \mathrm{W}$} & \multicolumn{2}{|l|}{$11^{\circ} 10^{\prime} \mathrm{N}-01^{\circ} 30^{\prime} \mathrm{W}$} & \multicolumn{2}{|l|}{$9^{\circ} 00^{\prime} \mathrm{N}-4^{\circ} 00^{\prime} \mathrm{W}$} \\
\hline Type of census & \multirow{2}{*}{\multicolumn{2}{|c|}{$\begin{array}{l}\text { Walk } \\
838.3\end{array}$}} & \multirow{2}{*}{\multicolumn{2}{|c|}{$\begin{array}{l}\text { Walk +Vehicle } \\
1469.6\end{array}$}} & \multirow{2}{*}{\multicolumn{2}{|c|}{$\begin{array}{l}\text { Walk } \\
657.0\end{array}$}} & \multirow{2}{*}{\multicolumn{2}{|c|}{$\begin{array}{l}\text { Vehicle } \\
3400.0\end{array}$}} \\
\hline $\begin{array}{l}\text { Distance } \\
\text { censused }(\mathrm{km})\end{array}$ & & & & & & & & \\
\hline
\end{tabular}

${ }^{1}$ Not available

${ }^{2}$ Absent from the study site

${ }^{3}$ (a) Average value for the whole of the census area, (b) near permanent watercourses

${ }^{4}$ Mean 1994-1998

${ }^{5}$ The geographical centre of the site

national and regional levels and that it protects a diversity of ungulates species, we recommend that the Park should be considered as one of the key areas for the conservation of ungulates in West Africa.

\section{Acknowledgements}

This study was funded by the European Union via the AGIR regional program. We thank Rod East and one anonymous reviewer for comments on the manuscript and Patrick Welby for the revision of the English.

\section{References}

Barnett, A.A. \& Prangley, M.L. (1997) Mammalogy in the Republic of Guinea: an overview of research from 1946 to 1996, a preliminary checklist and a summary of research recommendations for the future. Mammal Review, 27, 115-164.

Brugière, D. \& Magassouba, B. (2003) Mammalian diversity in the National Park of Upper Niger, Republic of Guinea - an update. Oryx , 37, 3 .

Buckland, S.T., Anderson, D.R., Burnham, K.P. \& Laake J.L. (1993) Distance Sampling: Estimating Abundance of Biological Populations. Chapman \& Hill, London, UK.

Cornelis, D. (2002) Analyse du monitoring écologique et cynégétique des populations des principaux ongulés au ranch à gibier de Nazinga (Burkina Faso). Rapport non publié, Faculté Universitaire des Sciences de Gembloux, Gembloux, Belgique.
East, R. (1999) African Antelope Database. IUCN, Gland, Switzerland.

Fisher, F. \& Linsenmair, K.E. (2001) Decreases in ungulate population densities. Examples from the Comoé National Park, Ivory Coast. Biological Conservation, 101, 131-135.

Galat, G., Galat-Huong, A. \& Mbaye, M. (1998) Densité et effectifs de quinze espèces de mammiferes et oiseaux terrestres diurnes du Parc National du Niokolo-Koba, Sénégal: évolution 1990 - 1998. Rapport non publié, DNPNS-ORSTOM, Dakar, Sénégal.

IUCN (2003) 2003 IUCN Red List of Threatened Species. IUCN, Gland, Switzerland and Cambridge, UK [http:/ / www.redlist.org, accessed 12 July 2004].

Kingdon, J. (1982) East African Mammals. An Atlas of Evolution in Africa. Volume IIIC. University of Chicago Press, Chicago, USA.

Kingdon, J. (1997) The Kingdon Field Guide to African Mammals. Academic Press, London, UK.

Laake, J.L., Buckland, S.T., Anderson, D.R. \& Burnham, K.P. (1994) DISTANCE User's Guide V. 3. Colorado State University, Fort Collins, USA.

Lamotte, M. (ed.) (1998) Le Mont Nimba - Initiation à la Géomorphologie et à la Biogéographie. UNESCO, Paris, France.

Pector, S. (2003) Biogeographic crossroads as priority areas for biodiversity conservation. Conservation Biology, 16, 1480-1487.

Sillero-Zubiri, C., Silvestre, I., Marion, G., Massaly S. \& Novelli, O. (1997) Distribution et abondance de quelques espèces clés de mammiferes dans le Niokolo Badiar. Rapport pour le Programme Régional d'Aménagement des Bassins Versants du Haut Niger et de la Haute Gambie (PRABV), Conakry, Guinée.

Touré, S., Soumah, S. \& Laurenti, A. (1997) Inventaire, distribution et abondance des mammiferes dans le Parc National 
du Haut Niger (Guinée). Rapport non publié, Programme Régional d'Aménagement des Bassins Versants du Haut Niger et de la Haute Gambie (PRABV), Conakry, Guinea. Ziegler, S. (1996) An initial study of hunting in the Upper Niger National Park. Wildlife \& Nature, 12, 13-29.

Ziegler, S., Nicholaus, G. \& Hutterer, R. (2002) High mammalian diversity in the newly established National Park of Upper Niger, Republic of Guinea. Oryx, 36, 73-80.

\section{Biographical sketches}

David Brugière was the principal technical adviser of the Haut Niger National Park (HNNP) for the EU-funded AGIR Program from December 2000 to March 2003. His research interests include the ecology and conservation of large and medium-sized mammals, and protected area management. He is a member of the IUCN/Species Survival Commission Primate and Antelope Specialist Groups.

Bakary Magassouba was trained at the Wildlife Specialists School, Garoua, Cameroon and was Director of the HNNP until March 2003. Souleymane Diakité was Co-director of the Park until March 2003.

Mamadou Dia, Marthe Gbansara, Maurice Mamy and Barry Saliou are officers at the Wildlife and Nature Protection Division within the Water and Forest National Direction, the governmental body responsible for natural resource management in Guinea. 